\title{
Enhanced visible light photocatalytic decolorization of azo dye using magnetic pani/ $\mathrm{CuFe}_{2} \mathrm{O}_{4} / \mathrm{ZnO}$
}

\begin{abstract}
In this study, novel magnetic hybrid of $\mathrm{PANI} / \mathrm{CuFe}_{2} \mathrm{O}_{4} / \mathrm{ZnO}$ was synthesized by in situ oxidative polymerization of aniline in the presence of $\mathrm{CuFe}_{2} \mathrm{O}_{4}$ as magnetic component and $\mathrm{ZnO}$ as photoactive component. The prepared sample was characterized by using $\mathrm{X}$-ray diffraction, Fourier transform infrared spectroscopy, field emission scanning electron microscopy and UV-vis spectroscopy. The catalytic activity of $\mathrm{PANI} / \mathrm{CuFe}_{2} \mathrm{O}_{4} / \mathrm{ZnO}$ was investigated by degradation of methyl orange (MO) in aqueous solution under visible light. The results indicated that the as prepared $\mathrm{PANI} / \mathrm{CuFe}_{2} \mathrm{O}_{4} / \mathrm{ZnO}$ show highly enhanced photocatalytic activity. Moreover, the $\mathrm{PANI} / \mathrm{CuFe}_{2} \mathrm{O}_{4} / \mathrm{ZnO}$ can be easily separated from the aqueous solution by an external magnet and reused for several cycles.
\end{abstract}

Volume 7 Issue I - 2018

Nahid Rasouli, Somayea Abasian

Department of Chemistry, Payame Noor University, Iran

Correspondence: Nahid Rasouli, Department of Chemistry, Payame Noor University, P.O. Box 19395-3697, Tehran, Iran, Emailn.rasooli55@yahoo.com,n.rasouli@pnu.ac.ir

Received: October 13, 2017 | Published: January 31, 2018

Keywords: polyaniline, magnetic, visible light, photocatalyst, zno

\section{Introduction}

Semiconductor research has demonstrated the main application in areas such as hydrogen production through photocatalytic water splitting, ${ }^{1}$ dye sensitized solar cells ${ }^{2}$ and photocatalytic treatment of harmful organics from air and water. ${ }^{3}$ Developing of efficient visible light responsive photocatalysts for environmental remediation has become the main area in photocatalysis research because of the usage of solar light. ${ }^{4}$ For the actual applications, $\mathrm{ZnO}$ photocatalysts are usually not suitable due to the inconvenient and expensive separation, ${ }^{5}$ high photocorrosion, ${ }^{6}$ and low quantum efficiency resulted from its wide band gap $\left(\mathrm{E}_{\mathrm{g}}=3.37 \mathrm{eV}\right)$ and the rapid recombination of photo-generated carriers. ${ }^{7}$ In this regard, the modified ZnO-based photocatalysis with conducting polymers such as PANI can respond to visible light region effectively. ${ }^{8}$ Moreover, $\mathrm{ZnO}$-based photocatalysis coupled with conducting polymers are difficult to separate and recover from aqueous solution. In this regard, $\mathrm{CuFe}_{2} \mathrm{O}_{4}$ as the important magnetic materials have been utilized with photocatalysts and allowing easy separation of the photocatalysts from the liquid after the photocatalytic process. ${ }^{9}$

\section{Synthesis of $\mathrm{PANI} / \mathrm{ZnCrFeO}{ }_{4} / \mathrm{ZnO}$ Photocatalyst}

The $\mathrm{PANI} / \mathrm{ZnCrFeO}_{4} / \mathrm{ZnO}$ sample was prepared by in situ polymerization of aniline on the surface of the $\mathrm{ZnCrFeO}_{4}$ and $\mathrm{ZnO}$ samples that reported previously. In this procedure, $10 \mathrm{~mL}$ of $0.1 \mathrm{M}$ aniline, $10 \mathrm{~mL}$ of 0.125 ammonium peroxydisulfate and $30 \mathrm{~mL}$ of $0.1 \mathrm{M}$ nitric acid solutions were added to $0.25 \mathrm{~g}$ of synthesized $\mathrm{ZnCrFeO}_{4}$ and $0.1 \mathrm{~g}$ of $\mathrm{ZnO}$ at room temperature. Then, the mixture was stirred during the polymerization of aniline, which was completed within 24 h. Finally, the prepared $\mathrm{PANI} / \mathrm{ZnCrFeO} / \mathrm{ZnO}$ was dried at $60^{\circ} \mathrm{C}$.

\section{Photocatalytic activity}

The control experiments were performed under visible light irradiation in the absence of the photocatalyst and in the presence of $\mathrm{ZnO}, \mathrm{CuFeO}_{4}, \mathrm{PANI} / \mathrm{CuFe}_{2} \mathrm{O}_{4} / \mathrm{ZnO}$ and polyaniline as photocatalysts under visible light irradiation.

\section{Mechanism of photocatalytic activity}

The photogenerated electrons of PANI can transfer to the conduction band of $\mathrm{ZnO}$ and $\mathrm{CuFe}_{2} \mathrm{O}_{4}$, and the holes from the valence band of $\mathrm{ZnO}$ and $\mathrm{CuFe}_{2} \mathrm{O}_{4}$ can transfer to HOMO of PANI. The photogenerated electrons can be captured by dissolved $\mathrm{O}_{2}$ to yield the $\mathrm{O}_{2}^{--}, \mathrm{HOO} \cdot$ and $\bullet \mathrm{OH}$ radicals and have been involved in the degradation of dye.

\section{Conclusion}

We provide a simple method to synthesize the magnetically recyclable PANI/CuFe ${ }_{2} \mathrm{O}_{4} / \mathrm{ZnO}$ photocatalyst by an in situ oxidative polymerization. The resulting sample show an enhanced photocatalytic activity for degradation of Methyl orange (MO). The photocatalytic decolorization percent of MO dye on the surface of the samples was determined about $45 \%, 5 \%, 98 \%$ and $55 \%$ for $\mathrm{ZnO}$ and $\mathrm{CuFeO}_{4}$, $\mathrm{PANI} / \mathrm{CuFe} \mathrm{O}_{4} / \mathrm{ZnO}$ and polyaniline samples, respectively. Also, $\mathrm{PANI} / \mathrm{CuFe}{ }_{2} \mathrm{O}_{4} / \mathrm{ZnO}$ sample can be reused three times with only gradual loss of activity.

\section{Acknowledgments}

The financial support of the research council of Payame Noor University of Isfahan is gratefully acknowledged.

\section{Conflicts of interest}

The authors declare no conflicts of interest.

\section{References}

1. Zhong DK, Sun JW, Inumaru H, et al. Solar water oxidation by composite catalyst $/ \alpha-\mathrm{Fe}_{2} \mathrm{O}_{3}$ photoanodes. JACS. 2009;131(17):6086-6087.

2. Gonzalez-Valls I, Lira-Cantu M. Vertically-aligned nanostructures of $\mathrm{ZnO}$ for excitonic solar cells:a review. Energy \& Environmental Science. 2009;2:19-34.

3. Kaneco S, Katsumata H, Suzuki T, et al. Titanium dioxide mediated photocatalytic degradation of dibutyl phthalate in aqueous solutionkinetics, mineralization and reaction mechanism. Chemical Energy Journal. 2006;125(1):59-66.

4. Feng J, Hu H, Yue PL. Discoloration and mineralization of orange II using different heterogeneous catalysts containing Fe:a comparative study. Environmental Science \& Technology. 2004;38(21):5773-5778.

5. Li Y, Wang $\mathrm{K}, \mathrm{Wu}$ J, et al. Synthesis of highly permeable $\mathrm{Fe}_{2} \mathrm{O}_{3} /$ $\mathrm{ZnO}$ hollow spheres for printable photocatalysis. RSC Advances. 2015;5(107):88277-88286. 
6. Han C, Yang MQ, Weng B, et al. Improving the photocatalytic activity and anti-photocorrosion of semiconductor $\mathrm{ZnO}$ by coupling with versatile carbon. Phys Chem Chem Phys. 2014;16(32):16891-16903.

7. Tang D, Ye H, Du D, et al. Fabrication of $\mathrm{ZnO} /$ graphene flake-like photocatalyst with enhanced photoreactivity. Applied Surface Science. 2015;358:130-136.
8. Eskizeybek V, Sarı F, Gülce H, et al. Preparation of the new polyaniline/ $\mathrm{ZnO}$ nanocomposite and its photocatalytic activity for degradation of methylene blue and malachite green dyes under UV and natural sun lights irradiations. Applied Catalysis B:Environmental. 2012;119:197206.

9. Sun $\mathrm{SH}$, Zeng $\mathrm{H}$, Robinson $\mathrm{DB}$, et al. Mono disperse $\mathrm{MFe}_{2} \mathrm{O}_{4}(\mathrm{M}=\mathrm{Fe}$, Co, Mn) nanoparticles. J Am Chem Soc. 2004;126(1):273-279. 